\title{
A DERIVA E SUAS PISTAS DENTRO DE UM PROGESSO DE GRIARSĨO GÊNIGA PELO MAR DE RUAS E PRAÇAS
}

RESUMO > Este artigo relata as experiências da Trupé de Teatro em processo colaborativo de criação cênica pelas ruas e praças do Centro da cidade de Sorocaba. Buscamos, aqui, pistas sobre a Deriva, o estado de Deriva - procedimento utilizado pelo grupo durante a pesquisa para a montagem de seus últimos espetáculos. Esse quase "diário de bordo" tem, assim, sua escrita nesse estado: um olhar sobre a Deriva em estado de Deriva.

Palavras-chave:

Deriva; Processos Criativos; Teatro de Rua. 


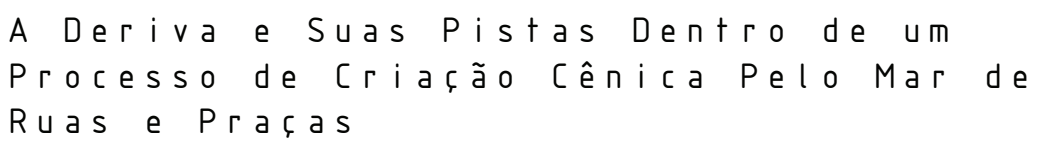

Carlos Alberto Doles Junior e Marcelo Ramos Lazzaratto

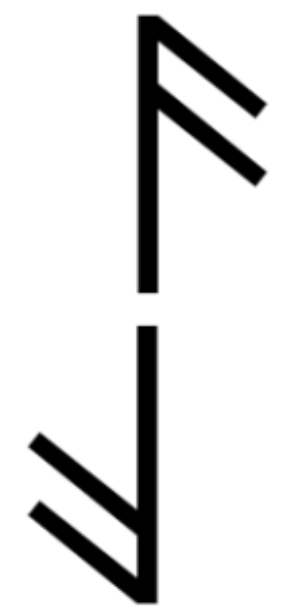

$>$ No início, o encontro com a Deriva

De repente, eu me vi à deriva, parado no meio do nada, olhando para tudo. Tudo parecia novo. Um raio precisava cair. E caiu. Depois de anos pesquisando de forma prática a linguagem do teatro popular e do teatro de rua, deparo-me com uma nova rua, uma nova praça, um novo espaço para ser explorado, visto, revisto, escrito, apagado, desenhado com rabiscos multicolores.

O espaço vivo, o cenário real, sempre me motivou, desde a época da graduação. Cenas e experimentos que surgiam do som da caneta batendo na tubulação de ar que passava na sala de aula, as rampas da universidade, jardins, áreas livres, pilastras, motivavam-me a criar e levavam-me a novas rotas, rumos, caminhos.

Tempos depois, como que por acaso, já mais amadurecido e tomado integralmente pelo oficio do teatro, percebi nos "espaços vivos" campo para desenvolver meu trabalho. Fachadas, praças e ruas eram minhas preferidas. Algo gritava. Parecia que via do cais um infinito mundo de possibilidades, o barco estava ali, era só içar a âncora e iniciar a navegação. E depois da queda daquele raio assim o fiz.

Barco, então, em nova rota. A rua era um rio de múltiplas águas; as praças, lagos e represas temporárias e a cidade, um mar a ser navegado. 
Desculpem-me, iniciei minha fala tão empolgado com as memórias, que esqueci de me apresentar: sou um ator/ diretor. Nesse momento, por conveniência e convenção, intitular-me-ei de Capitão dessa jornada. Talvez mais no sentido de possuidor de uma bússola ilusória (que muitas vezes mais leva ao estado de estarmos perdidos) do que de chefe de algo. Afinal essa chefia é compartilhada. Todos somos chefes de tudo e, acima de tudo, de nosso próprio processo exploratório.

Somos sete. Sete na equipe que navega há mais de quatro anos só nesse trecho de mar, digo, as ruas e praças do Velho Centro da cidade de Sorocaba, no interior de São Paulo. E reforço: fui incumbido temporariamente de carregar essa bússola, de conduzir o leme e organizar alguns mapas e pistas que nos chegam.

Nós sete, a equipe de navegação e descobertas, jogamo-nos nesse mar em pesquisa movidos por um desejo de experimentar, de colocar-nos em risco e de falar desses lugares, nesses lugares. E é por isso que aqui estou: tentando cartografar alguns pedaços de jornada na pretensão de deixar algumas pistas a outros navegantes, navegadores, exploradores. Sem grandes e falsas pretensões, apenas a de relatar algumas rotas percorridas e de, quem sabe, trocar saberes e tesouros.

Para que eu possa iniciar, de fato, esse relato, e buscar registrar aqui uma série de aglomerações de vivências e conceitos, preciso antes apontar algumas questões fundamentais que nos norteiam nessa navegação: qual a magia desconhecida que o espaço vivo exerce sobre o trabalho de criação do ator dentro do seu processo criativo em um grupo que opta pelo trabalho colaborativo? Qual a razão de encontrarmos na comunhão com uma praça, uma viela, um banco, um poste, grande motivação para criação? E quando somos assistência, quando presenciamos um ator utilizando esses espaços para seu fazer artístico, para seu dizer teatral, o que nos motiva a parar e olhar? $O$ que me leva a perceber esse corpo extracotidiano, no espaço comum do cotidiano, alterando o tempo, o ritmo, as cores, a luz e o fluxo desses espaços? O que me faz parar e perceber aquela praça, aquele poste, aquela viela, a estátua, que sempre ali esteve, mas agora, com aquele ou aqueles corpos em ação, berra diante de meus olhos, dilata e explode meus ouvidos? E eu, criador, pesquisador, corpo, ator, comunhão de criação com esse espaço, por força de um ou outro estimulo - teórico-formal, poético-dramático, etc - como reajo a esses novos olhares, a esses novos ouvidos que pararam ali durante meu ensaio criativo para presenciar o efêmero inacabado?

As questões acima surgiram durante a jornada, em fluxo de navegação, em comunhão com a criação e os espaços. E são essas questões que nos impulsionam a continuar em fluxo, em jornada e em navegação. Por meio delas, chegamos a possíveis rotas. E é sobre uma dessas rotas que desejo falar: a Deriva.

Tratada essa, agora, como um procedimento potente por nossa equipe de navegadores, o preceito que nos interessa na Deriva é o de que para se encontrar é preciso se perder. Estar em Estado de Deriva pressupõe, logo, surpreendermo-nos por um desvio de rota, sem rumo certo. Em nosso caso especificamente, vemo-nos perdidos no meio do conhecido centro urbano, lotado de referências afetivas, históricas, pessoais, local desejado para o nosso fazer, pesquisar e criar. É ali que nos colocamos em estado de Deriva. 
Como Capitão da embarcação, ao perceber a potência desse procedimento em curso, descoberto meio que por acaso (fato bem típico da própria Deriva), pensei que seria prudente buscar pistas de outros navegadores que, propositalmente, aventuraram-se no mar aberto. Sem demora me encontrei com Guy Debord, que me dizia:

\section{(...) a deriva se apresenta como uma técnica de passagem rápida por ambiências variadas. O conceito de deriva está indissoluvelmente ligado ao reconhecimento de efeitos de natureza psicogeográfica è à afirmação de um comportamento lúdico-construtivo, o que o torna absolutamente oposto às tradicionais noções de viagem ou passeio. (DEBORD, 1958. In: JACQUES, 2003, p.87)}

\footnotetext{
${ }^{1}$ O termo Psicogeografia é uma constante nas pistas de Debord e nos escritos da Internacional Situacionista. Para eles, Psicogeografia é o "estudo dos efeitos exatos do meio geográfico, conscientemente planejado ou não, que agem diretamente sobre o comportamento afetivo dos indivíduos" (IS, in: JACQUES, 2003, p.65).

${ }^{2}$ Grupo que surge em 1957 e se mantém atuante até o início da década de 70, teve como uma de suas questões principais dar visibilidade à perda de um certo "caráter lúdico" nas cidades. Atuantes como críticos do Urbanismo Moderno, através de seu Urbanismo Unitário (UU), os situacionistas propuseram uma nova forma de apropriação e percepção da arte, arquitetura e urbanismo, segundo uma ótica que os aproximava da vida cotidiana, mas, ao mesmo tempo, buscava trazer à tona a paixão e a emoção relacionadas à cidade. (DIAS, 2007, p.211)
}

Chego, então, à Teoria da Deriva. E nela encontro estímulo para essa navegação criativa que nos propusemos. Aparece-me com clareza uma possível estratégia baseada no quanto o ambiente influencia no meu comportamento afetivo e o quanto ele pode ser motivador para o meu sistema cognitivo e perceptivo; definitivo, portanto, nas minhas tomadas de decisões no meu processo criativo.

$\mathrm{E}$ isso me interessa potencialmente nessa navegação. Percebo, pois, o ambiente plurívoco para o encontro de ideias que ela, a Deriva, poderia nos proporcionar. Essa certeza se consolida quando Debord, em mais uma pista, adverte:

Uma ou várias pessoas que se lançam à deriva estão rejeitando, por um período mais ou menos longo, os motivos de se deslocar e agir que costumam ter com os amigos, no trabalho e no lazer, para entregar-se às solicitações do terreno e às pessoas que nele venham a encontrar. (...) Mas, em sua unidade, a deriva tem ao mesmo tempo esse deixar-se levar e sua contradição necessária: o domínio das variações psicogeográficas exercido por meio do conhecimento e do cálculo de suas possibilidades. (DEBORD, 1958. In: JACQUES, 2003, p.87)

MembrodaInternacionalSituacionista ${ }^{2}$, Debord propõe uma deriva no intuito de promover novas percepções da cidade, novos caminhos e rotas. Ele indica um estado de liberdade afetiva e de reconhecimento urbano - e nisso me encontro. Ele sugere, em suma, um jogo de relação entre indivíduo e espaço, na busca de uma ludicidade que, segundo ele e seus pares, andava há muito esquecida. 
Os Situacionistas se auto-definiram "indivíduos que se dedicam a construir situações". Segundo as significações disponibilizadas no livro "Apologia da Deriva" (uma espécie de caixa de pistas para mim), Situação Construída é "Momento da vida, concreta e deliberadamente construído pela organização coletiva de uma ambiência unitária e de um jogo de acontecimentos" (IS, in: JACQUES, 2003, p.65).

Com isso, outra pista-pergunta chega até mim em relação a nossa navegação à Deriva: como perceber ou criar novas situações tendo o cotidiano como ponto de partida? Proposital e temporariamente deixando de lado essa nova indagação, eu continuo...

Parece-me interessante tudo isso. Compartilho, com euforia, as pistas descobertas com os outros seis tripulantes. Paraminhasurpresa osvejotambém eufóricos com as inúmeras pistas e encantados com tamanha imensidão de possibilidades. Dessa intersubjetividade, vejo então, ao longe, ilhas que me provocam a seguir navegando.

$\mathrm{Na}$ embarcação, cada qual com seus próprios instrumentos, olhamos juntos "ao redor" e compartilhamos nossas visões. A certa altura, um dos navegantes da equipe, $o$ Baixinho de Nariz Protuberante, apresentanos duas novas pistas, ainda sobre a construção de situações. A primeira diz:
A ideia de construir situações propõe que a vida cotidiana poderia incitar paixões que provocam um sentido de jogo no espaço urbano, onde, apesar da repetição de hábitos, abre-se sempre um espaço para $o$ aleatório, o incontrolável, o apaixonante.

(DIAS, 2007, p.211)

O aleatório, aquilo que sai do controle mesmo que temporariamente, forjando a ressignificação espaço-temporal daquilo já conhecido, parece ser a meta buscada na Deriva. Isto é, enxergar o "quelque chose de plus"3 em contraponto à normatividade instituída e a lógica comum da cidade.

Em seguida, a segunda pista que o navegante do Nariz Protuberante nos traz vem do próprio Debord:

A vida do homem é uma sequência de situações fortuitas e, embora nenhuma delas seja exatamente semelhante a outra, são em sua imensa maioria tão indiferenciadas e insossas que dão a impressão de serem iguais. O corolário desse estado de coisas é que raras situações interessantes que conhecemos numa vida retêm e limitam rigorosamente essa vida. Devemos tentar construir situações, isto é, ambiências coletivas, um conjunto de impressões determinando a qualidade de um momento (DEBORD, 1957. In:

JACQUES, 2003, p. 56).

A navegante Ruiva, a mais velha entre nós, tripulantes, entende essa pista como um chamado para a experimentação. Ela parece reconhecer nesse escrito algo de latente em nosso trabalho: um olhar outro para o velho conhecido - diz ela em meio às suas constatações. Reflete, ainda, que nossa Deriva, inicialmente ancorada nos preceitos da Deriva de Debord e dos Situacionistas, ganha outras dimensões - concluindo então. 
Com isso percebemos que a Deriva nos serve, interessa-nos mesmo. Verificamos, porém, que será necessário realizar um deslocamento.

Afinal, quando saímos em nossas pequenas embarcações por um espaço urbano pré-definido estamos abertos ao acaso, ao inusitado, à percepção e/ou à produção espontânea de situações. Mas esse estado de Deriva, de estar perdido no achado, além de revelador de novas relações espaciais, transborda-nos novidades dos fluxos sociais, de suas questões e provocações.

Nosso deslocamento vai, contudo, além: saímos em busca do novo no velho conhecido, mas temos por trás uma proposição muito clara: como esses espaços, esses fluxos nos afetam? Despertam-nos o desejo criativo? Inundam-nos de questões a serem investigadas? Provocam nosso corpo à experimentação cênica? Como podemos dialogar com a cidade, na cidade, falando da Cidade? E como não cristalizamos todas essas questões de forma hermética para, a posteriori, apresenta-las à própria cidade?

E lá estamos eu e meus amigos envoltos em mais uma série de novas questões e tão-somente uma resposta até aqui: a de que a Deriva talvez nos traga muito mais novos questionamentos do que possíveis soluções às questões anteriores, o que nos lança em novas correntes, porém em rota desgovernadamente serena de navegação; porque a cidade já nos tocou, já nos motivou. Eis o quanto bastava.

Então, pressinto que devo agora falar de nossas Derivas. De como Debord nos empurra, meio século depois, para o mesmo inusitado e nos provoca ao deslocamento necessário. Foram inúmeras as vezes que nos lançamos, em duplas ou trios, nas ruas de nosso campo de trabalho. Delimitamos um espaço geográfico e o subdividimos em episódios, em partes para a investigação. Temos tempo definido para a viagem (cerca de duas horas) e a proposição de que o espaço indique as rotas, as velocidades e as paradas.

Cada grupo tem liberdade de empreender seus procedimentos e escolhas: velocidade e intensidade de deslocamento, tempo de pausa em determinados pontos, direções a seguir, refazer caminhos, etc, optando ou não pelo registro material de sua deriva: anotações, fotos, vídeos, isto é, daquilo que se produziu em razão da troca de impressões durante o percurso com seus companheiros.

Depois de encerrado o tempo, reuníamo-nos em um ponto estabelecido para a discussão das impressões, sensações e motivações geradas. Repetimos esse procedimento diversas vezes, trocando percursos, parceiros de duplas, horários e tempo de navegação à Deriva. E novas trocas de experiências e novas percepções. E o corpo começando a reagir, a se motivar. A cidade proporcionava espaço para a criação.

Depois de um desses procedimentos de Deriva, como Capitão, propus que cada navegante, de acordo com suas razões, escolhesse entre todos os espaços visitados e reconhecidos, um que lhe chamou a atenção. Talvez eu buscasse, assim, perceber os efeitos da Deriva em nossa navegação, mensurar sua identificação com o nosso processo. Pedi que voltassem para esses lugares, descobertos pela Deriva e que lá se prostrassem durante um determinado período de tempo. A Deriva agora seria micro na relação espacial. Como se colocar em um estado de escuta, à Deriva, de um micro espaço? 
Parece que essa visita nos apresenta novas noções da organização, percebidas por André Carreira em seus estudos sobre A Cidade como Dramaturgia e o Teatro de Invasão. Novas pistas parecem chegar dentro de garrafas em pleno mar aberto:

É interessante poder pensar a presença extra-cotidiana do teatro na rua como um estímulo a uma desordem que se aproxima de projetos de Deriva (DEBORD). Kevin Linch em seu livro de 1960 A imagem da cidade observava que "perder-se completamente talvez seja uma experiência bastante rara para a maioria das pessoas que vivem na cidade moderna". Essa dificuldade está relacionada com os processos de orientação característicos das cidades contemporâneas, que buscam diminuir ao máximo as margens para o acaso $e$ a deriva. O comportamento da deriva identificado por Guy Debord representa sempre uma ameaça às lógicas ordenadoras que aparentemente, dão forma à cidade. Reconhecer a imprevisibilidade significa aceitar a possibilidade, ainda que momentânea, de uma completa inversão de papéis sociais, e até mesmo da desorganização da ordem estabelecida. (CARREIRA, 2007, p.04)

Parece que essa pista vinha ao encontro com as discussões pós-deriva, com nossos anseios de gerar ação e com esse novo olhar conquistado pelos navegantes.

Após essa experiência de Deriva no micro espaço, cada um foi provocado a criar uma escrita livre (na ideia de registro de experiência) acerca desse processo final de escuta e observação. Parece que agora encontrávamos um farol norteador para o inicio da criação. Mal sabíamos que a criação já estava iniciada há tempos. Esses textos foram trocados entre nós. O que eu havia escrito foi lido por outros olhos e escutado por outros ouvidos. Também foram compartilhados os locais escolhidos. Um navegante apresentava a outro o seu local. Chegamos à provocação final desse grande circuito de derivas: cada navegante deveria escolher um local (o seu, que já havia reconhecido, ou outro, escolhido por outro navegador, que talvez lhe parecesse mais inusitado e cheio de novidades) para realizar uma situação, propor um acontecimento com base nas questões impressas em seu texto e nos textos compartilhados. Ou seja, cada navegante tinha em mãos uma série de possibilidades, de direções e escolhas a serem feitas sem critérios estabelecidos. Percebo aí um deslocamento do estado de Deriva do âmbito espacial para o do procedimento de criação.

Agora, cada integrante da equipe de navegadores, ainda em Deriva, teria o tempo de uma semana para elaborar procedimentos, disparadores, lógicas, elementos cênicos, etc. para o seu acontecimento, para a sua situação que iria ser presenciada por toda a equipe e por quem mais por ali estivesse.

>A Deriva que gera Situações ainda à Deriva

O Mar cidade é amplo e repleto de ilhas, portos, faróis. Espaços que podem ser lidos e relidos. Esses espaços, para nossa tripulação, parecem ser fonte de desejo de pesquisa e disparador de potências criativas. A Deriva nos ajudou, e muito, a olhar para todo esse mar. Para percebê-lo em ininterrupto fluxo de mudança. Mesmo com a ideia de alguns portos seguros (um texto escrito, outros lidos, espaços explorados e cuidadosamente observados, ouvidos e sentidos) sabíamos que nesses espaços mora o inusitado, o vivo. Esse parecia ser o motor da ação: o risco de se colocar em jogo e descobrir como lidar com o acaso em jogo. Acaso esse que se manteria sempre, mesmo após a falsa sensação de domínio. Mas 
também existe uma tensa relação no que entendemos como acaso, que parece ser tão inerente ao processo de Deriva na rua, mas talvez não seja. Quem percebe essa tensão em relação ao termo e suas sensações é a navegante dos cabelos Cacheados. Olha só diz ela - existe um perigo na relação com o acaso, escutem isso. Foi quando nos leu em voz alta uma pista encontrada na teoria da Deriva:

O acaso ainda tem importante papel na deriva porque a observação psicogeográfica não está de todo consolidada. Mas a ação do acaso é naturalmente conservadora e tende, num novo contexto, a reduzir tudo a alternância de um número limitado de variantes e ao hábito. Como o progresso consistirá, pela criação de novas condições mais favoráveis a nosso desígnio, na ruptura de um dos campos onde ocorre o acaso, é possivel afirmar que os acasos da deriva são fundamentalmente diferentes dos do passeio, e que os primeiros atrativos psicogeográficos descobertos correm o risco de fixar o sujeito ou o grupo derivante em torno de novos eixos habituais, para os quais tudo os leva constantemente. (DEBORD, 1957. In: JACQUES, 2003,

Então - completa o Baixo do Nariz Protuberante - o próprio acaso inicial pode se cristalizar e tendenciosamente se transformar em forma fixa... E eu, em minhas derivas, vou acabar forjando este estado, achando que estou sendo levado pela psicogeografia, mas não estou? - concluiu. A Ruiva, a Cacheada, O Alto Forte, a Menina Crespa, a Esbelta e eu, entendemos que sim. O acaso, tão importante ao processo de Deriva, reconhecido como diferente do acaso cotidiano, do passeio e da rotina, pode gerar novos eixos, novas fórmulas cristalizadas e pré-definidas que nada têm a ver com o próprio acaso, abortando assim a espontaneidade do processo. Então, a Menina Crespa diz que precisamos estar atentos para não deixar $o$ estado de Deriva dissolver, precisamos nos manter atentos na presença, ouvindo e vendo de verdade o espaço, as pessoas, abrindo brechas reais em nossa percepção para a composição. Todos concordamos com sua afirmação, mas no fundo brotava ali mais uma questão provocadora: Como se manter assim? Achamos melhor voltar à prática e deixar que a ação de estar em experiência nos indicasse caminhos, que já sabíamos não serem exatos.

Voltamos, então, ao preparo das situações nos espaços escolhidos, buscando manter o estado de Deriva, descoberto, discutido e até desconfiado por todos nós. Uma proposição e vários possíveis rumos a serem tomados pelos atores navegadores, era o que tínhamos em nosso barco. Coloco-me neste jogo junto com toda a tripulação. Eu que derivei com eles, que também escolhi um lugar por algum tipo misterioso de afetação, que escrevi, li escritos inspiradores, que encontrei no espaço à Deriva derivações para a criação. Junto todo esse material e busco, intuitivamente, colocar-me em processo criativo. Penso, escrevo, formato.

Nesse tempo dedicado à criação (duração de uma semana) navego pelos afluentes, rios, córregos das questões. Um verdadeiro complexo hídrico de possibilidades. As várias provocações se multiplicavam e inúmeras saídas brotavam em minha imaginação, na minha vontade e no meu corpo. Figuras aparecem em meu criar. A lembrança, a memória do espaço escolhido, me afeta e me coloca em dúvida. Será que o espaço do qual me recordo, que há menos de dois dias era presencial, é o mesmo? Será que o que estou planejando será possível? E como abro espaço para a criação, para o inusitado do momento? Como me jogo em Deriva mesmo estando já com alguns balizadores, com rotas traçadas? 
$\mathrm{O}$ risco do acaso verdadeiro e a impossibilidade da previsibilidade total chegam como pista na voz de André Carreira:

O elemento de risco é um componente recorrente no exercício de apropriação da cidade, em primeiro lugar porque esta é um sitio no qual está presente uma série de riscos para a vida e integridade física das pessoas. Ainda quando os riscos dizem respeito mais ao imaginário e respondem a uma tensão que parece típica de nossas cidades estes compõe uma percepção de uma condição fundamental do urbano. A rua é o espaço inóspito

\footnotetext{
${ }^{4}$ Termo cunhado por Carreira que diz respeito a um pensar o Teatro na rua a partir das questões da própria cidade através de um diálogo continuo entre cidade e a obra artística. Segundo ele "aparecem atualmente formas espetaculares que não se contentam com estar na rua, mas buscam incorporar no funcionamento da cena os fluxos da rua, ou por outro lado, subverter estes fluxos fabricando rupturas dos ritmos cotidianos. Quando me refiro à ideia de 'invasão', não me refiro, necessariamente, a um ato de rebeldia, oriundo em grupos criativos marginais. A invasão, ainda que seja um gesto político não nasce sempre impulsionado por uma motivação politizada claramente definida". (CARREIRA, 2007, p.02)

${ }^{5}$ Minha proposta de ação, ou acontecimento ou cena, consistia em: eu vestido com um casaco que lembrava um militar, aparecer para a plateia na esquina de uma pequena rua sombria e deserta com outra um pouco mais larga e também deserta que é passagem dos ônibus intermunicipais, ambas de paralelepípedos, e me apresentar como o Cuidador das Fronteiras. Depois de arrastar umas lixeiras que serviriam de apoio para uma caixa de giz, iniciaria o meu trabalho de reforçar a escritura "PARE" impressa no chão. A ação acabaria quando todas as letras estivessem recuperadas e reforçadas pelo giz. Nesta ação fui afetado pelos espectadores que reagiam a ação, pelo movimento das pessoas curiosas no entra sai do bar na esquina, pelo passar de tempos em tempos dos ônibus. Todos esses elementos contribuíram para o estado, para a presença e para a criação de uma ficção coletiva.
}

que se opõe ao conforto e segurança dos espaços íntimos e é isso que atrai o olhar do artista como ponto de partida do processo criativo. Nesta situação o espetáculo se aproximaria das condições que se assemelham aos momentos fundacionais do teatro antes que essa linguagem fosse enclausurada nos espaços fechados, e altamente estratificados das salas teatrais. (CARREIRA, 2007, p.06)

Assumo, então, o risco e seu medo positivo. Reconheço em mim esse receio que Carreira aponta e, mais que isso, o fascínio e a sedução contidos nele. Penso em uma proposta de ocupação, ou invasão ${ }^{4}$ que me permita espaço para a porosidade, para o fluxo, as afetações e a sua percepção. Algo que ponha em prática o que acabo de reconhecer. Assim, o espaço da rua, descoberto sensivelmente em percurso em Deriva, agora é provocador da criação e será ele, no instante da realização presencial deste ato invasivo, o mantenedor do estado da Deriva que o gerou. Escolho uma ou outra ação balizadora amarradas por um pensamento objetivo do que quero dizer. Estabeleço para mim um ponto de partida e uma ação finalizadora. Sei o que fazer, mas esse caminho só poderá de fato ser percorrido no momento da ação ${ }^{5}$.

Então realizamos o exercício. Depois de organizarmos previamente a ordem dos acontecimentos pensados por cada tripulante, colocamo-nos na rua mar em busca dos locais que serão invadidos.

A aventura em pleno mar se inicia. Agora, parece que realizaremos mais um deslocamento: A Deriva que levou a um espaço - que produziu inspiração, provocação que gerou uma experiência, uma invasão, um acontecimento, um programa de ação - não é passado, não é pré-procedimento, continua sendo a base da ação. 
Nesse exercício pude experimentar o jogo entre assistir e ser assistido, provocar e ser provocado e parece que na rua esses lugares se esbarram e por vezes se misturam. Como plateia de outro ator também me sentia em risco. Havia incertezas nos deslocamentos, eu estava em Deriva, pois não sabia exatamente para aonde estava sendo levado, onde eu deveria parar para ver aquela cena, além de também me sentir provocando quando reconhecia que eu era parte da imagem, da ação. Já quando fui o propositor da cena, ali, naquele espaço que me suscitou tanta coisa, procurava no outro, seja ele o passante desavisado da rua ou o colega de navegação, relação, olhar, respiração na tentativa da porosidade, de encarar o inusitado e o risco que tanto me fascinavam.

Tanto material, tantas pistas. Poderia eu aqui, neste momento de minha escritura, relatar com riquezas de detalhes (tanto de ordem material quanto sensível) o que vi e o que fiz. Seriam páginas e páginas de interessantes relatos e de inúmeras percepções de quanto o inusitado, o acaso e o risco compuseram as interferências e se materializaram em cenas. Mas, creio ser mais potente destacar alguns momentos que nos trazem pistas mais claras. Um deles vem do relato da Cacheada que opta em sua Deriva por uma escadaria que liga duas ruas do Velho Centro. Ruas que, após às $19 \mathrm{~h}$ se transformam em arquipélago, repleto de ilhas ocupadas por garotas de programas rodeados por marinheiros e navegadores em busca de amor entre outros seres típicos das ilhas noturnas dos Velhos Centros das cidades médias. A Cacheada nos conta:

- A escadaria entre duas ruas meu espaço cênico, minha zona de desconforto. Fora da caixa, mas ainda assim potente, vivo e vibrante em seus fluxos noturnos. Propusme a ressignificá-la como binóculo, de onde observava as roupas, o medo, os homens, os

carros, o estranho, a sexualidade, o desejo e o silêncio. Invadi o não-espaço com apenas uma condição: ouvi-lo. Dessa escuta meticulosa e difícil surgiram reflexões a cerca das relações existentes naquele espaço, das intervenções que causei em seu ritmo, dos fluxos de energia, da minha capacidade de permeabilidade e percepção das suas questões sociais e urbanas. Tudo isso reduzido a três palavras: medo relação - sapatão. Considero importante falar sobre o medo e o risco antes de falar da criação no não-espaço, justamente por serem dois fatores primordiais para a vulnerabilidade do corpo não corpo, para a abertura dos poros. Risco e medo me proporcionaram tônus para a cena não cena, um tônus aberto, vazado, titubeante, de estado de alerta e ao mesmo tempo aberto ao porvir. Andar melindroso, certeiro, atento, aberto. Nas palavras de Eleonora Fabião:

“(...) cuidadosamente atento a si, ao outro,
ao meio; é o corpo da sensorialidade
aberta e conectiva. A atenção permite
que o macro e o minimo, grandezas que
escapam na lida cotidiana, possam ser
adentradas e exploradas." (FABIÃO, 2010,p.322)

Sem esse estado corpóreo não haveria aderência ao meio.

A cena, experiência, invasão da Cacheada consistia em colocar-nos sentados na escadaria, no local que quinze dias antes sentara, em sua Deriva na observação que relatou acima. Tirou os sapatos e só de meias recolheu do chão um cigarro. Olhou-nos e perguntou se alguém tinha fogo. Depois da negativa de todos, ela desceu as escadarias caminhando para o lado direito da rua de baixo. Navegou até a ilha da esquina onde estavam duas garotas de programas. Depois de uma rápida conversa inaudível devido à distância, uma das garotas acendeu seu cigarro. Ela parece agradecer e retorna, em nossa direção. Em nossa frente, outra ilha, ali, do outro lado 
da rua de baixo, uma pequena rotatória com grama baixa e um poste com luzes queimadas no centro. E foi ali o lugar que ela escolheu para atracar. Em posição sensual, podíamos perceber que a Cacheada se colocava na condição das garotas daquelas ilhas. Mas sem nenhuma caracterização, figurino, trejeitos, nada. Ali, tendo toda a tripulação como testemunha, fumava seu cigarro só de meias. Carros passavam, pessoas passavam, o fluxo da vida seguia. Até que um carro, para, abruptamente, escondendo a imagem da Cacheada. O sujeito no carro conversa com ela. Minutos de suspensão para mim. O carro parte, a Cacheada fica. Volta a sua ação. Termina seu cigarro. Atravessa a rua, sobe as escadas, coloca seu tênis, e nos convida a seguir para a próxima cena.

Muitas questões surgiram após presenciarmos essa experiência. $\mathrm{O}$ ficcional e o real haviam se esbarrado. Perguntava-me: esse carro estava previsto? Era combinado? Eu sabia que não, mas a dúvida me chegou, de verdade. Até que ponto ou até aonde ela podia ir? Até que ponto o espaço se mistura com a ação? E o que passou pela cabeça da Cacheada? O que foi dito naqueles minutos de conversa? Como foi se colocar em risco, misturar o real a sua ação, mas não deixar de estar em atividade artística?

\footnotetext{
${ }^{6}$ Pope L. performer citado por Eleonora Fabião no artigo "Programa Performativo: $O$ Corpo-em-experiência” publicado na Revista do LUME, n.4, dez, 2013.

${ }^{7}$ A Cacheada nestes relatos é Thais Almeida, atriz e arte-educadora que compõe o Núcleo Pesquisa de Criação e Experimentação Cênica em Espaços Vivos do Grupo Trupé de Teatro em Sorocaba. Estes trechos foram cedidos pela atriz e fazem parte de seu diário de bordo.
}

Em reunião posterior a apresentação das cenas, já no cais do porto com os barcos atracados, divido minhas dúvidas com ela. Ela comenta:

- Sobre a linha tênue entre factual e ficcional, digo que me fascinam as possibilidades de questionamento que esse campo de vivência abre para refletirmos sobre nossa condição históricohumana. Minha invasão instalou uma situação de encontro, emprestei o meu binóculo para que as testemunhas presentes pudessem ver além de. Não sinto que subverti, mas que atenuei. Que passei caneta marca texto naquele fluxo. Que o desafiei. Será que aquele homem não viu que eu estava só de meias? Quem para o carro pra uma mulher só de meias? Eis uma questão importante, um segredo a ser compartilhado, que pode desencantar as testemunhas vibrantes pelo "será que é real?" e ao mesmo tempo dar a elas certa "receita": eu convidei aquele homem. Eu chamei-o de volta. Quando o carro passou pela primeira vez o que fiz foi olhar diretamente nos olhos do condutor. Do começo ao fim, sem interrupções, de peito aberto, no aqui e no agora. O que não imaginava era que ele voltaria. Pois é, voltou. (Pausa) Entendem? (Pausa). A gente conversou antes. Pelos olhos. Segundo Pope. $L^{6}$ não fiz arte, fiz conversa.

Mas onde mora o convite, mora também o medo do encontro e prefiro encerrar meu relato, questionando. Não na busca de respostas, mas de facilitações. De caminhos que facilitem o meu diálogo com o outro sem que essa linha tênue da liminaridade conceituada por Victur Turner, estoure. Pois o corpo era outro. Como o ator banca o inusitado? Como o ator ficciona com o real? Creio que minha experiência criativa me deu mais questões do que elementos para a criação de novas percepções. No entanto, quem para o carro pra uma mulher só de meias? Meias. $^{7}$

A Cacheada, em seu depoimento, lança nossos olhares à potencialidade dos "Programas Performáticos" pensados por Eleonora Fabião como pistas para esse processo de pesquisa e criação nas ruas. Outra de nossas companheiras, a Esbelta, muito empolgada 
com o rumo das experiências, indicanos a pista exata, dizendo que programas performativos são "um conjunto de ações previamente estipuladas, claramente articuladas e conceitualmente polidas a ser realizado pelo artista, pelo público ou por ambos sem ensaio prévio" (FABIÃO, 2013, p. 04). Neste momento o navegador Alto Forte, o mais novo entre nós, que vem estudando com grande afinco os conceitos de Performance em um curso de formação, percebe que esse procedimento, apesar de, até certo ponto, ser planejado com antecedência, ainda propicia um estado de Deriva em sua execução, pois não há ensaio. A Ruiva interfere dizendo que mesmo não tendo ensaiado, se este ator não se colocar em estado de jogo, de escuta e percepção, a Deriva pode não acontecer: creio que a Deriva acaba quando o ator se fecha nos preceitos que preparou; na ânsia de só executar o planejado da maneira planejada. Eu acredito - continua a Ruiva - que esse tipo de relação não condiz muito com o criar na rua na perspectiva que pretendemos. E só falo isso por perceber uma profunda diferença em mim, no meu corpo e na minha ação quando busco estar em jogo com o todo e sinto essa diferença por já ter passado por experiências na rua onde o que me importava era dar conta do que eu tinha proposto e da maneira como havia planejado e se algo estranho a isso ocorresse e modificasse o rumo da ação, eu encarava essa situação como erro e desvio de rota. Hoje - conclui - percebo que o desvio de rota pode ser um importante material e caminho para mim.

Então me coloco na discussão: Eleonora diz que o navegante em curso, através dos procedimentos dos Programas Performativos, "suspende o que há de automatismo, hábito, mecânica e passividade no ato de 'pertencer' - pertencer ao mundo, pertencer ao mundo da arte e pertencer ao mundo estritamente como 'arte"' (FABIÂO, 2013, p.05). E ainda recorro a Carreira quando fala dos desafios no processo criativo no Teatro de Invasão:

\begin{abstract}
Não há preparação - ensaio - que possa responder, do ponto de vista da tarefa interpretativa, a todas as variáveis que necessariamente funcionarão no momento da "invasão". Consequentemente, $o$ trabalho do ator que se prepara para "invadir" não deverá supor a plena realização no projeto dos ensaios, mas construir um instrumental que se defina pela capacidade da adaptabilidade. (CARREIRA, 2007, p.05)
\end{abstract}

Pertencer, fazer parte, estar em estado criativo, com escuta dilatada. A Deriva deslocada para a criação teatral na rua, para o Teatro de Invasão, para a cidade como dramaturgia, parece-nos um procedimento bem atraente, de múltiplas possibilidades e desdobramentos, ainda mais quando correlacionada com as pistas dos Programas Performativos que poderão ampliar o campo de experiência do ator em curso de pesquisa criativa, abrindo a ele novas rotas com "outras temporalidades, materialidades, metafisicalidades, experimentando mudanças de hábitos psicofísicos, registro de raciocínios e circulações energéticas; acessado dimensões pessoais, politicas e relacionais" (FABIÃO, 2013, p.08).

Parece que esse tipo de espaço é deveras instigante para a criação, experimentação e realização artística. Esse é um pequeno consenso dessa equipe de navegantes em pleno mar. E talvez o mar seja, por enquanto, uma metáfora adequada para nosso campo, para esse espaço inóspito da rua; A Deriva é um disparador eficaz para esses navegantes que começam a entender (no sentido mais variável da palavra entendimento) seus fluxos inconstantes. De fato, é um perder-se para poder se achar. É uma tentativa incessante de dilatação do olhar e do ouvir para não "ignorar a fala da cidade que se expressa pela articulação do desenho dos edifícios, das vias, de seus pontos nodais, bem como do fluxo e do repertório dos usos sociais" (CARREIRA, 2007, p.03). 
Em tempo continuamos em navegação, eu, o Capitão provisório, e os outros seis tripulantes, em busca de mais pistas para esse ator em ato criativo em pleno mar aberto das praças, asfaltos, passantes, ocupantes e postes. 


\section{REFERÊNCIAS BIBLIOGRÁFICAS}

\section{$>$ Livros}

CARREIRA, André. A cidade como dramaturgia do teatro de "invasão". XI Encontro Regional da ABRALIC, 2007.

DEBORD, Guy. Teoria da deriva (1958). In: JACQUES, P. B. (Org.). Apologia da Deriva: Escritos situacionistas sobre a cidade. Rio de Janeiro: Casa da Palavra, p. 87-91, 2003.

FABIÃO, Eleonora. Corpo cênico, estado cênico. Revista Contrapontos, vol.10 n.3, p. 321-326, 2010.

INTERNACIONAL SITUACIONISTA - IS. Definições (1958b). In: JACQUES, P. B. (Org.). Apologia da Deriva: Escritos situacionistas sobre a cidade. Rio de Janeiro: Casa da Palavra, 2003, p. 65-66.

>Publicação On-line

DIAS, Juliana M.M. "O Grande Jogo do Porvir": A Internacional Situacionista e a ideia de jogo urbano. Rio de Janeiro: Estudos e Pesquisas em Psicologia UERJ, v.7 n.02, p. 210-222, 2007. Disponível em: http://www.revispsi.uerj.br/v7n2/artigos/pdf/v7n2a06.pdf

FABIÃO, Eleonora. Programa Performativo: O corpo-em-experiência. Campinas: ILINX-Revista do LUME, 4 ed, 2013. Disponível em: http://www.cocen.unicamp.br/revistadigital/index.php/lume/article/ view/276

\section{ABSTRACT}

This article describes the experiences of the "Trupé de Teatro" in coloborative process of scenic creation using streets and squares of Sorocaba Centre Ville. We seek clues here about the Dérive, the status of dérive: the procedure used by the group during the search for the assembly of his last shows. So, this is almost a "board diary" whose words have been written in this state; a look of the "Dérive" in state of "Dérive".

\section{KEYWORDS}

Dérive; Creatives Process, Street Theatre 